\title{
Hak-Hak Pekerja Rumah Tangga dan Perlindungan Hukum di Indonesia
}

\author{
Muhammad Yafi Azhari dan Abdul Halim \\ yafiazhr27@gmail.com \\ Universitas Pembangunan Nasional Veteran Jakarta
}

Keywords:
Domestic workers;
Legal protection;
Regulation.

\section{Abstract}

The purpose of this study is to analyze the rights of informal domestic workers and legal protection in Indonesia through Law Number 13 of 2003 concerning Manpower and Regulation of the Minister of Manpower (Permenaker) Number 2 of 2015 concerning Protection of Domestic Workers. This type of research is qualitative using a normativeempirical approach. Sources of data include primary data in the form of interviews, while secondary data through statutory approaches and document studies. The results show that the rights of domestic workers have not been fully regulated to provide a decent life for domestic workers and the drafting of Permenaker No. 2 of 2015 has not become a state protection for domestic workers because the regulation focuses on supervising channeling agencies. Therefore, government awareness of the existence of domestic workers is necessary.

\section{Kata Kunci: $\quad$ Abstrak}

Pekerja Rumah Tujuan dari penelitian ini untuk menganalisis hak-hak pekerja rumah tangga Tangga; Perlindungan Hukum; Pengaturan. informal dan perlindungan hukum di Indonesia melalui Undang-Undang Nomor 13 Tahun 2003 tentang Ketenagakerjaan dan Peraturan Menteri Ketenagakerjaan (Permenaker) Nomor 2 Tahun 2015 tentang Perlindungan Pekerja Rumah Tangga. Jenis penelitian ini kualitatif dengan menggunakan pendekatan normatif-empiris. Sumber data meliputi data primer berupa wawancara sedangkan data sekunder melalui pendekatan ilmu perundang-undangan dan studi dokumen. Hasil menunjukan bahwa hak pekerja rumah tangga belum diatur secara lengkap untuk memberi kehidupan yang layak bagi PRT dan pembuatan Permenaker Nomor 2 Tahun 2015 belum menjadi perlindungan negara kepada pekerja rumah tangga karena peraturan tersebut berfokus untuk mengawasi lembaga penyalur. Oleh karena itu perlu kesadaran pemerintah terhadap keberadaan pekerja rumah tangga. Copyright (C) 2021 Muhammad Yafi Azhari dan Abdul Halim. (cc)(i) (() Published in Media Iuris. Published by Universitas Airlangga, Magister Ilmu Hukum.

\section{Pendahuluan}

Pekerja Rumah Tangga merupakan pekerjaan yang dibutuhkan sekarang ini, hampir setiap keluarga memiliki pekerja rumah tangga untuk mengurusi rumah karena tidak memiliki waktu untuk mengurusnya dikarenakan sibuknya pekerjaan diluar rumah. Hal ini terjadi di kehidupan masyarakat perkotaan, setiap perempuan modern bukan lagi hanya menjadi ibu rumah tangga namun juga merupakan pekerja di ruang lingkup publik. Oleh karena kebiasaan ini menyebabkan meningkatnya pekerjaan sebagai PRT di luar sana. 
Meskipun begitu perhatian negara terhadap pekerja rumah tangga masih sangat minim menyebabkan maraknya kasus terhadap para pekerja di ruang lingkup keluarga ini.

Kasus pekerja rumah tangga merupakan permasalahan yang kerap terjadi tiap tahunnya di Indonesia, permasalahan yang terjadi pada pekerja rumah tangga berupa kekerasan gender, seksual dan perdagangan orang. Selain diskriminasi, pekerja rumah tangga juga belum memiliki kehidupan yang layak karena ketentuan haknya belum juga dipenuhi.

Keberadaan PRT sampai saat ini belum diakui sebagai tenaga kerja yang sama dengan tenaga kerja lainnya. Dalam kehidupan sosial Pekerja Rumah Tangga dianggap sebagai pembantu. Banyaknya jumlah pekerja dalam lingkup Pekerja Rumah Tangga sudah selayaknya mendapatkan perhatian lebih. Berdasarkan laporan Kementerian Negara Pemberdayaan Perempuan yang menggambarkan kondisi PRT saat ini di Indonesia, yaitu: sebagian besarnya adalah perempuan, dengan usia belum dewasa, dalam kondisi buruk, tanpa batas waktu kerja, serta mengalami kekerasan dan penghambaan (domestic slavery).

Menurut perkiraan ILO jumlah pekerja rumah tangga di negara maju rendah, pada $0,9 \%$ dan di negara berkembang menyumbang proporsi yang jauh lebih besar di Amerika Latin dan Karibia, 11,9\% diikuti dengan Timur Tengah 8,0\%, Afrika 4,9\%, dan Asia 3,5\%. ILO mengatakan terdapat 52,6 juta pekerja di dunia, jika dilihat data maka pekerja rumah tangga merupakan sumber pekerjaan penting.

Di Indonesia jam kerja pekerja rumah tangga informal bekerja 6 atau 7 dalam seminggu dan 40 jam atau lebih seminggu, mendapatkan Rp. 1.000 .000 perbulan, provinsi PRT terbesar adalah Jawa barat yakni 859.000. Menurut data ILO kuurang lebih 70,49 juta orang bekerja di bidang informal, dimana $61 \%$ diantaranya pekerja perempuan. Total sekitar 9 juta pekerja melakukan perpindahan, $60-70 \%$ adalah perempuan sebagai pembantu rumah tangga diluar negeri. Data 2015 jumlah PRT di Indonesia diperkirakan sampai 4 juta.

Data catatan Komnas Perempuan, dipastikan bahwa kekerasan terhadap perempuan masih kerap terjadi, terutama kekerasan dalam KDRT/RP. Tercatat 
pada tahun 2015 terdapat 11.207 kasus kekerasan terhadap perempuan di dalam keluarga dan/hubungan pribadi, diantaranya PRT. Menurut Laporan Kementrian Pemberdayaan Perempuan Nasional, laporan menggambarkan situasi PRT Indonesia saat ini yaitu sebagian besar perempuan, anak dibawah umur, dalam situasi buruk, tidak memiliki batasan jam kerja, dan mengalami kekerasan dan perbudakan. ${ }^{1}$ Pada saat yang sama, menurut catatan tahunan Komite Nasional Antri Kekerasan terhadap Perempuan, jumlah ini meningkat setiap tahun. Mengalami pertumbuhan yang sangat tinggi mencapai 35\% di tahun 20111 dan 2012. Tahun 2015 jumlah kasus meningkat $9 \%$ dibandingkan tahun $2014 .^{2}$

Jaringan Advokasi Pekerja Rumah Tangga Indonesia menunjukkan bahwa dari tahun 2007 hingga 2011, Indonesia mengalami 726 tindak kekerasan serius terhadap PRT, termasuk 536 kasus tunggakan upah, di mana 348 adalah PRT dan Kasus penyekapan, penganiayaan, hingga luka berat sampai meninggal dunia berjumlah 617 kasus. ${ }^{3}$ Berdasarkan data dari suara.com, Pekerja rumah tangga mengalami PHK sepihak, dirumahkan dan pengurangan gaji, karena pandemi Covid-19 berdampak besar kepada pekerjaan dan kesehatan. Selain itu dihimpun JALA PRT, 417 PRT mengalami kekerasan seperti kekerasan fisik, psikis, dan ekonomi pada tahun 2020 ini.

Perekrutan menjadi sistem kerentanan untuk pekerja rumah tangga, perekrutan terdiri menjadi dua, berasal dari perantara informal (teman/calo) atau agen penyalur. Beberapa kasus telah menunjukan perantara calo berbahaya karena meminta komisi kepada PRT, tidak hanya itu jika pekerja mengajukan pertanyaan, perantara calo akan mengancam dan menyalahgunakan ancamannya, namun bentuk terburuk dari semua mereka akan melakukan pelecehan seksual.

\footnotetext{
${ }^{1}$ Maslihati Hidayati, ‘Upaya Perlindungan Pekerja Rumah Tangga Sebagai Kelompok Masyarakat Yang Termarjinalkan Di Indonesia' (2011) Vol 1 No.1 Jurnal Al-Azhar Indonesia Seri Pranata Sosial.[8].

${ }^{2}$ Ranny Intan Raflis, Nur Rochaeti and Dyah Wijaningsih, 'Perlindungan Hukum Bagi Pekerja Rumah Tangga Perempuan Korban Tindak Kekerasan' (2016) 5 Diponegoro law.[1].

${ }^{3}$ Nur Hidayati, 'Perlindungan Terhadap Pembantu Rumah Tangga (PRT) Menurut Permenaker No . 2 Tahun 2015’ (2014) 14 Ragam Jurnal Pengembangan Humaniora.[213]. <https:// jurnal.polines.ac.id/index.php/ragam/article/view/512>.
} 
Beberapa studi sebelumnya telah mengkaji mengenai hak-hak pekerja rumah tangga informal yaitu Sitti \& Irwansyah (2020) mengatakan kelompok pekerja rumah tangga tidak dijangkau oleh peraturan UU Ketenagakerjaan, ${ }^{4}$ Hanifah (2020) mengatakan kalau kepentingan mendesak dalam merumuskan kebijakan untuk melindungi PRT di dalam dan di luar negeri, ${ }^{5}$ Sonhaji (2020) mengatakan Implementasi Peraturan Menteri Nomor 2 Tahun 2015 tentang Perlindungan Pekerja Rumah Tangga tidak berjalan lancar, serta terdapat kekurangan dan kendala, ${ }^{6}$ Muwahid (2017) Pekerja rumah tangga (PRT) tidak diklasifikasikan sebagai pekerja dalam undang-undang ketenagakerjaan, sehingga hak-hak dasarnya sebagai pekerja tidak dijamin,7 Ingrid (2018) mengatakan Indonesia belum meratifikasi Konvensi ILO No. 189 tentang pekerja layak bagi pekerja rumah tangga padahal pengaturan mengenai hubungan kerja sudah dituangkan dalam konvensi tersebut, ${ }^{8}$ Kartika (2018) mengatakan bahwa perlu diratifikasi Konvensi ILO No. 189 tahun 2011 tentang Pekerjaan Layak bagi Pekerja Rumah Tangga dalam upaya memperkuat perlindungan hukum hak-hak pekerja rumah tangga, meningkatkan kepentingan ekonomi pekerja rumah tangga, dan meningkatkan derajat pekerja rumah tangga Indonesia. ${ }^{9}$

Penelitian ini memiliki pembedaan yaitu perlindungan hukum di Indonesia denganmengandalkan peraturan menteri lebihmengatur secara komperhensif Lembaga Penyalur ketimbang hak yang dibutuhkan PRT dan belum terdapat sanksi pidana demi meningkatkan kekuatan hukum. Selain itu, kepentingan hak PRT bukan menjadi skala prioritas melainkan lebih memfokuskan peraturan kepada lembaga penyalur.

\footnotetext{
${ }^{4}$ Sitti Magfirah Makmur and Irwansyah Reza Mohammad, 'Tinjauan Hukum Perlindungan Tehadap Pekerja Rumah Tangga' (2020) 1 Jurnal At-Tanwir Law Review.[43].

${ }^{5}$ Ida Hanifah, 'Kebijakan Perlindungan Hukum Bagi Pekerja Rumah Tangga Melalui Kepastian Hukum' (2020) 17 Legislasi Indonesia.[193].

${ }^{6}$ Sonhaji Sonhaji, 'Perlindungan Pekerja Rumah Tangga Dalam Sistem Hukum Nasional' (2020) 3 Administrative Law and Governance Journal.[250].

${ }^{7}$ Muwahid, 'Perlindungan Hukum Terhadap Buruh Wanita Sektor Pekerja Rumah Tangga (PRT) Di Kota Surabaya' (2017) 1 Mimbar Yustiti 1 <http://e-jurnal.unisda.ac.id/index.php/mimbar/article/view/901>.

${ }^{8}$ Gwendolyn Utama and Vienna Melinda, 'Pengaturan Dan Perlindungan Hukum Bagi Pekerja Rumah Tangga Di Indonesia’ (2018) 11 Arena hukum.[139].

${ }^{9}$ Kartika Dewi Mulyanto, 'Urgensi Ratifikasi Konvensi Pekerjaan Yang Layak Bagi Pekerja Rumah Tangga Oleh Pemerintah Indonesia' (2018) 1 Undang: Jurnal Hukum.[109].
} 
Tujuan dilakukan penelitian ini untuk menganalisa hak pekerja rumah tangga informal dan perlindungan hukumnya di Indonesia. Berdasarkan hak PRT yang diatur dalam Peraturan Menteri Tenaga Kerja Nomor. 2 tahun 2015 belum cukup memungkinkan untuk PRT menjalani kelayakan hidup, dan kekuatan hukum PRT dianggap begitu lemah. Oleh karena itu, dimulai dengan argumen bahwa hak-hak pekerja rumah tangga informal belum dilindungi undang-undang nasional. Artikel ini mengangkat beberapa pertanyaan penting. Bagaimana hakhak pekerja rumah tangga informal dan bentuk perlindungan hukum diIndonesia terhadap hak-hak pekerja rumah tangga informal jika terjadi pelanggaran.

\section{Metode Penelitian}

Jenis penelitian yang digunakan adalah kualitatif. Penggunaan pendekatan penelitian berupa normatif dan empiris. Penelitian hukum normatif-empiris, meliputi metode hukum (legal method) dan metode konseptual (metode konseptual). Penelitian ini menggunakan data primer dan data sekunder. Data primer, data mentah dari wawancara, peneliti mewawancarai orang-orang yang bekerja sebagai pembantu rumah tangga masing-masing bernama Liawati, Erni, serta Sri Harti, pengambilan data wawancara Liawati dan Erni dilakukan di bogor di tempat mereka masing-masing bekerja, dan Sri Hartati pengambilan data wawancara di depok di tempatnya bekerja. Dan pendekatan ilmu perundangundangan (Statutical approach) serta studi dokumen dalam data sekunder. Teknik analisis yang dalam penelitian ini adalah deskriptif kualitatif, menggunakan data kualitatif dari deskripsi deskriptif untuk mencari solusi masalah yang diangkat. Teknik ini dilakukan dengan cara membentuk aturan, urutan, logika dan kalimat efektif sehingga mempermudah pemahaman.

\section{Hak-Hak Pekerja Rumah Tangga Informal}

Dalam lingkup pekerjaan di Indonesia, salah satu kelompok yang kurang beruntung adalah seseorang yang menjadi pekerja rumah tangga (PRT). Mereka memasuki perekonomian informal, biasanya bekerja dalam keluarga, dan tidak 
berada dalam lingkup pengaturan pekerjaan umum. Tentunya halinimembutuhkan perhatian khusus para PRT. Dalam laporan hukum online ILO (halaman 10), dijelaskan: "Pemerintah menetapkan bahwa majikan pembantu rumah tangga dapat diklasifikasikan sebagai "pemberi kerja", namun tidak tergolong badan usaha dan pengusaha dalam artian UU". Oleh karena itu bahwa pekerja rumah tangga dianggap tidak dipekerjakan oleh pengusaha, dan “UU Ketenagakerjaan” tidak memberi mereka perlindungan bagi pekerja sektor informal. Maka selama ini hak pekerja rumah tangga tidak dilindungi oleh undang-undang, dan ikatan dengan majikan sebatas kepercayaan antar keduanya.

Pekerja adalah setiap penduduk dalam usia kerja yang melakukan kegiatan ekonomis, baik dalam hubungan kerja di perusahaan maupun di luar hubungan kerja seperti pekerja mandiri, pekerja keluarga dan pekerja di sektor informal lainnya. Dan dalam pasal 1 angka 3 UU Ketenagakerjaan menyatakan bahwa "Pekerja adalah setiap orang yang bekerja dengan menerima upah atau imbalan dalam bentuk lainnya" dan Pasal 1 angka 4 UU Ketenagakerjaan menyatakan "Pemberi kerja adalah orang perseorangan, pengusaha, badan hukum, atau badan-badan lainnya yang mempekerjakan tenaga kerja dengan membayar upah atau imbalan dalam bentuk lain." Apabila melihat isi dari pasal tersebut ketentuan dan unsur dari pekerja sudah memenuhi PRT, maka PRT juga merupakan pekerja karena dipekerjakan oleh perseorangan namun UU Ketenagakerjaan masih tidak mencapainya untuk melindungi PRT.

Permenaker nomor 2 tahun 2015 telah memuat tentang hak pekerja rumah tangga pada pasal 7 dan kewajiban pekerja rumah tangga pada pasal 8. Selain itu juga pada pasal 5 peraturan ini mengatur bahwa para pihak harus mencapai kesepakatan tertulis atau lisan, yang berbunyi "Pengguna dan PRT wajib membuat perjanjian kerja tertulis atau lisan yang memuat hak dan kewajiban dan dapat dipahami oleh kedua belah pihak serta dikehetahui oleh ketua Rukun Tetangga atau dengan sebutan lain".Nnamun dalam peraturan tersebut memuat kata "wajib" untuk melangsungkan kesepakatan. Istilah "wajib" menjadi kabur saat kesepakatan kerja disepakati secara lisan. Kata wajib dikaitkan dengan 
kesepakatan tertulis, menunjukkan bahwa ada perlindungan hukum. Namun, jika istilah "wajib" terkait kesepakatan lisan, maka tidak ada perlindungan hukum karena tidak cukup bukti pada saat terjadi sengketa. ${ }^{10}$ Menurut data dilapangan, masih banyak PRT yang tidak memiliki perjanjian tertulis dan hanya berdasarkan kepercayaan.

Bersumber pada hasil wawancara dengan Liawati, Erni, serta Sri Harti yang dilakukan di rumah tempat mereka bekerja, menarangkan kalau Permenaker Nomor 2 Tahun 2015 belum dapat memenuhi hak kepada PRT, masih ada kekurangan bila dibanding dengan UU Nomor 13 Tahun 2003. Kekurangan tersebut berbentuk:

1. Perjanjian

Perjanjian dalam permenaker perlu diatur daya paksa untuk para pihak membuat kesepakatan secara tertuls. Peraturan pembuatan perjanjian sudah diatur dalam pasal 5 dan 6 permenaker, tapi karena tidak adanya kekuatan hukum belum terlaksana dengan baik. Hasil penelitian menghasilkan kalau PRT masih belum memiliki kesepakatan dengan pengguna walau telah ada peraturan ini, karena tidak ada daya paksa dan sanksi. Karena perjanjian merupakan hal terpenting untuk membangun hubungan antar pemberi dan pekerja untuk melindungi hak dan kewajibannya. Jika tidak diterapkannya suatu perjanjian maka pemberi kerja atau majikan tidak akan memiliki tanggungjawab hukum bila melakukan ketidaksewenangan kepada Pekerja Rumah Tangga.

2. Upah

PRT memiliki gaji dibawah 1 juta, jelas belum memenuhi kehidupan layak pekerja. Permenaker perlu menetapkan gaji yang diterima PRT, seperti Upah minimum Kota layaknya UU Ketenagakerjaan. Bisa juga memberikan batasan tersendiri upah khusus untuk PRT agar dapat sedikt memenuhi kebutuhan hidupnya. Tunjangan dan jaminan sosial telah didapatkan tetapi ketentuannya

${ }^{10}$ Abdul Khakim. “Aspek Hukum Perjanjian Hubungan Kerja, Peraturan Perusahaan Dan Perjanjian Kerja Bersama (PKB)” (PT. Citra Aditya Bakti 2017).[111]. 
tidak dituliskan dalam perjanjian maka jumlahnya tidak diketahui. Serta upah apabila pekerjaannya melampaui jam yang sudah ditetapkan sebelumnya, perlu diatur untuk jasa yang sudah diberikan oleh PRT.

3. Waktu Kerja

Pemerintah perlu memperhatikan jam kerja untuk PRT seperti layaknya pekerja formal. Tentu perlu dilakukan untuk kepentingan hukum yang jelas. Hasil wawancara, PRT memiliki jam kerja yang berbeda-beda, karena saat PRT bekerja lebih lama maka pekerjaan yang ada banyak sebaliknya jika sedikit maka bisa selesai lebih cepat. Dan untuk PRT yang menginap dirumah majikannya alahkah baiknya diberi ketetapan jam kerja dan istirahatnya, tidak sewenangnya bekerja dari pagi hingga malam.

4. Cuti

Ketentuan cuti dari Permenaker hanya sebatas "memang perlu dilakukan" berbeda seperti UU Ketenagakerjaan diatur secara terperinci. Hasil lapangan menjelaskan PRT memiliki cuti di hari raya dan bila mendapat izin pengguna, perlu diatur ketentuan cuti seperti memberikan cuti 2 atau 3 kali kepada PRT dalam setahun. Untuk hari libur sudah didapatkan PRT namun untuk pengaturan hari libur belum dimuat dalam peraturan dan beberapa PRT masih bekerja meskipun dihari libur.

Pengaturan hak sudah ditetapkan dalam permenaker akan tetapi pelaksanaannya belum diterapkan dengan baik. Hak yang didapat juga tidak selengkap UU Ketenagakerjaan, selain hak yang disebutkan tadi, mekanisme penyelesaian perselisihan juga belum diatur secara pasti. Sebab permenaker ini tidak mendasarkan pada bab X UU Ketenagakerjaan, bab ini memuat ketentuan seperti kesejahteraan, perlindungan dan pengupahan, maka hak pekerja dalam UU Ketenagakerjaan tidak menjadi milik PRT. ${ }^{11}$ Karena itu nasib dari PRT hanya bergantung pada tanggungjawab dari penggunanya.

${ }^{11}$ Ayu Pariutami and I Made Udiana, 'Perlindungan Hukum Terhadap Hak Pekerja Rumah Tangga Yang Tidak Sesuai Dengan Perjanjian Dibawah Tangan' (2020) 8 Kertha Semaya, Jurnal Ilmu Hukum.[1291]. 
Berdasar tanggapan dari Lita Anggraini Koordinator JALA PRT menyatakan bahwa pelanggaran kepada PRT menjadi hal yang lumrah dan dapat mengarah menjadi perbudakan modern sementara mandat dari UU sendiri negara harus mengakhiri perbudakan, ini terjadi apanila hak dalam Permenaker tidak diperjelas seperti dalam UU.

Undang-Undang Perlindungan Pekerja Rumah Tangga sangat dibutuhkan karena selain tujuan utamanya melindungi pekerja rumah tangga yang bekerja di dalam negeri, juga membantu meningkatkan perlindungan bagi pekerja rumah tangga Indonesia yang bekerja di luar negeri. ${ }^{12}$ Perlindungan terhadap PRT memang sudah ditetapkan, namun masih belum cukup untuk melindungi hak dan kepentingannya.

Negara harus menjamin perlindungan terhadap PRT dengan memberikan hak-hak yang layak di bidang ekonomi dan sosial serta juga menghentikan kekerasan diskriminasi. Hal ini selaras dengan sila kedua dan kelima Pancasila yaitu "Kemanusiaan yang Adil dan Beradab", dan "Keadilan sosial bagi seluruh rakyat Indonesia" serta ketentuan dari Konstitusi Undang-undang Dasar Negara Kesatuan Republik Indonesia Pasal 28D ayat (2) yang menyatakan, “Setiap orang berhak untuk bekerja serta mendapat imbalan dan perlakuan yang adil dan layak dalam hubungan kerja".

\section{Bentuk Perlindungan Hukum di Indonesia Terhadap Hak-Hak Pekerja Rumah} Tangga Informal Jika Terjadi Pelanggaran.

Negara Indonesia adalah negara yang berkonsep hukum, seperti ditetapkan Pasal 1 ayat 3 UUD 1945, Indonesia adalah negara hukum. Salah satu asasnya adalah perlindungan hak asasi Manusia. ${ }^{13}$ Akan tetapi negara hukum demokratis sekedar mitos yang belum terbukti, karena negara hukum belum tercipta secara komperhensif seperti diatur dalam konstitusi yang mengakibatkan pelanggaran

\footnotetext{
${ }^{12}$ Hanifah, Op.Cit.[198].

${ }^{13}$ Andryan, 'Implikasi Putusan Hak Uji Materil Di Mahkamah Agung Terhadap Legalitas Pimpinan Dewan Perwakilan Daerah Republik’ (2018) 18 Jurnal Penelitian Hukum De Jure.[127].
} 
HAM masih sering terjadi. Menurut Sudikno Mertokusumo, hukum melindungi kepentingan manusia. Sebagaimana dijelaskan dalam UU No. 39/1999, HAM adalah hak asasi manusia yang melekat dan harus dihormati oleh setiap orang. Menurut undang-undang, HAM dapat memberikan kekuatan moral untuk melindungi dan menjamin martabat manusia. Namun negara hukum belum terbentuk secara keseluruhan sesuai dengan ketentuan konstitusi, sehingga sangat rawan terjadi pelanggaran hak asasi manusia. ${ }^{14}$

Pekerja Rumah Tangga memiliki perlindungan hukum akan tetapi peraturan tersebut terbagi secara terpisah untuk melindunginya, yaitu UUD 1945, KUHP, UU No. 23 Tahun 2004 tentang Penghapusan Kekerasan dalam Rumah Tangga, UU No. 23 Tahun 2002 tentang perlindungan Anak, UU No. 20 Tahun 2002 tentang sistem pendidikan Nasional dan UU No. 39 Tahun 1999 tentang hak asasi manusia. Meskipun banyaknya peraturan tersebut, belum mengatur secara langsung Pekerja Rumah Tangga. Oleh karena itu pemerintah mengeluarkan Permenaker No. 2 Tahun 2015 tentang Perlindungan PRT. Tetapi peraturan tersebut masih memiliki kekurangan.

Permenaker tentang PPRT tidak mengacu “UU Ketenagakerjaan” karena akan rumit, terutama jika menyangkut persoalan serikat pekerja dan mekanisme penyelesaian sengketa. Sebelumnya, Menteri Ketenagakerjaan mengklaim permenaker ini lebih dari KILO Nomor 189 tentang kerja layak bagi PRT. Menurut Pasal 3 KILO 189, pekerja rumah tangga perlu dipandang layaknya pekerja lain di sektor formal. Namun jika permenenaker ini tidak didasarkan pada UU Ketenagakerjaan, kapasitas Permenaker tidak bisa sebagai penunjang jauh di bawah standar minimal. Disarankan agar permenaker berdasarkan pada "UU Ketenagakerjaan" atau peraturan terkait ketenagakerjaan, karena PRT juga merupakan pekerjaan.

UU Nomor 23 Tahun 2014, PP Nomor 38 Tahun 2007, dan Kepres Nomor 121. Tahun 2014 merupakan landasan dibuatnya permenaker, pembuatannya

${ }^{14}$ Dessy Artiana, 'Politik Hukum Kesetaraan Gender Di Indonesia' [2010] Ilmu Hukum Universitas Riau.[48]. 
salah kaprah dengan tidak merujuk pada UU Ketenagakerjaan, hal ini menjadi alasan bahwa peraturan menteri ini sebagai bentuk pengawasan kepada Lembaga Penyalur.

Alasan UU No. 23 Tahun 2014, menjadi dasar adalah dibutuhkan adanya pengawasan terhadap instansi penyalur di masing-masing daerah. ${ }^{15}$ Tetapi, Kewenangan Menteri Tenaga Kerja dalam rangka penyelenggaraan pemerintahan daerah telah dibatasi untuk urusan pemerintah pusat, provinsi serta kabupaten/kota. ${ }^{16}$ Kemudian Peraturan Pemerintah Nomor 38 Tahun 2007, yaitu untuk menghindari tumpang tindih wewenang. Kemudian Kepres 121/2014 menetapkan bahwa pembentukan Kementerian Ketenagakerjaan memiliki dasar hukum. ${ }^{17}$

Tujuan pembuatan peraturan ini untuk melindungi PRT, meskipun dalam peraturan ini memuat persyaratan, perjanjian, hak, dan kewajiban dari PRT. Akan tetapi substansi permenaker mengatur LPPRT lebih komperhensif seperti:

a. Perizinan

Lembaga PRT perlu memiliki perizinan yaitu SIU-LPPRT dari Gubernur yang didapatkan dengan mengajukan permohonan secara tertulis. Permohonan akan diverifikasi tanpa dipungut biaya.

b. Jangka waktu

Jangka waktu yang diberikan paling lama 5 tahun dan diperpanjang untuk jangka waktu paling lama juga 5 tahun.

c. Perpanjangan izin

Perpanjangan SIU-LPPRT diajukan 30 hari sebelum berakhirnya masa berlaku, perpanjangan tersebut dapat dilakukan dengan mengajukan permohonan perpanjangan secara tertulis kepada Gubernur dan bila tidak memperpanjang surat izin perlu dikembalikan

\footnotetext{
${ }^{15}$ Choirunnisa and Rainingsih Hardjo, 'Analisis Proses Terbentuknya Peraturan Menteri Ketenagakerjaan Republik Indonesia Nomor 2 Tahun 2015 Tentang Perlindungan Pekerja Rumah Tangga' Fisip UI'.

${ }^{16}$ Makmur and Mohammad, Op.Cit.[50].

${ }^{17}$ Choirunnisa and Hardjo, Op.Cit.[10].
} 


\section{d. Kewajiban LPPRT}

Mengatur kewajiban LPPRT yaitu menyeleksi calon pengguna; memastikan calon PRT kondisi sehat; memantau PRT yang disalurkan; dan mengembalikan imbalan jasa jika PRT tidak bersedia melanjutkan untuk bekerja.

e. Sanksi kepada LPPRT

Sanski yang diberikan berupa sanksi administratif berupa peringatan tertulis; penghentian sementara sebagian atau seluruh; dan pencabutan izin.

Berdasarkan substansi permenaker tentang PPRT, lebih mementingkan pengaturan kepada lembaga penyalur. Untuk Sanski, tidak memuat sanksi kepada majikan dan juga tidak memuat sanksi pidana untuk memperkuat payung hukum kepada Pekerja Rumah Tangga malah hanya sebatas sanksi administratif yang ditujukan kepada Lembaga Penyalur. Oleh karena itu peraturan ini berfokus kepada Lembaga Penyalur dan masih terdapat kelemahan hukum.

Kelemahan lain yaitu hasil lapangan menjelaskan bahwa pekerja rumah tangga yang bekerja tanpa melalui Lembaga Penyalur tidak tahu dengan Permenaker ini, sehingga substansi dalam permenaker tidak dapat diterapkan, maka perlu penambahan ketentuan untuk pekerja rumah tangga yang ingin bekerja harus melalui Lembaga Penyalur untuk diberikan pengetahuan soal peraturan ini. Tidak hanya itu, pekerja rumah tangga yang akan bekerja ini dapat dipantau oleh lembaga penyalur dan dapat diberikan pelatihan untuk meningkatkan kompetensi keterampilan dari pekerja rumah tangga yang akan disalurkan. Lalu dapat mengetahui substansi dari Permenaker.

Ketentuan sanksi perlu dibuat berdasarkan pada UU Ketenagakerjaan, penambahan sanksi pidana diperlukan untuk keselamatan bekerja pekerja rumah tangga. Maka itu pemerintah perlu lebih peduli dengan pekerja pada bidang informal khususnya pekerja rumah tangga agar dapat mengurangi hal-hal yang buruk terjadi dan perlindungan hak-hak yang sesuai dengan hasil kerja yang dilakukannya. 


\section{Kesimpulan}

Perlindungan terhadap hak Pekerja Rumah Tangga Informal diatur dalam Permenaker No. 2 Tahun 2015 tentang Perlindungan Pekerja Rumah Tangga. Kehidupan layak bagi PRT masih belum tercapai mengingat hak yang diatur belum terpenuhi, hak seperti 1. Upah, 2. Jam kerja, 3. Perjanjian, 4. Cuti, dan 5. Penyelesaian Sengketa, semestinya perlu dimuat peraturan ini dengan berpatokan pada UU Ketenagakerjaan. Kepentingan hak dibutuhkan guna keberlangsungan hidup yang lebih baik untuk PRT.

Perlindungan Hukum di Indonesia menggunakan penerapan permnaker, akan tetapi pembuatannya masih salah kaprah dengan tidak berdasar pada UU Ketenagakerjaan, maka dari itu substansi dari peraturan ini berfokus pada ketentuan Lembaga Penyalur dibandingkan kepentingan hak pekerja rumah tangga. Sanksi yang diberikan juga belum memberikan kepastian hukum karena tidak dimuatnya sanksi pidana melainkan hanya sebatas sanksi administratif. Pemerintah harus memperhatikan pekerja disekotr informal khususnya pekerja rumah tangga.

\section{Daftar Bacaan}

\section{Buku}

Abdul Khakim, Aspek Hukum Perjanjian Hubungan Kerja, Peraturan Perusahaan Dan Perjanjian Kerja Bersama (PKB) (PT Citra Aditya Bakti 2017).

\section{Jurnal}

Andryan, 'Implikasi Putusan Hak Uji Materil Di Mahkamah Agung Terhadap Legalitas Pimpinan Dewan Perwakilan Daerah Republik’ (2018) 18 Jurnal Penelitian Hukum De Jure.

Dessy Artiana, 'Politik Hukum Kesetaraan Gender Di Indonesia' (2010) Jurnal Ilmu Hukum Universitas Riau.

Choirunnisa and Hardjo R, 'Analisis Proses Terbentuknya Peraturan Menteri Ketenagakerjaan Republik Indonesia Nomor 2 Tahun 2015 Tentang Perlindungan Pekerja Rumah Tangga'. 
Muhammad Yafi: Hak-Hak Pekerja...

Hanifah I, 'Kebijakan Perlindungan Hukum Bagi Pekerja Rumah Tangga Melalui Kepastian Hukum' (2020) 17 Legislasi Indonesia.

Ida Hanifah, 'Kebijakan Perlindungan Hukum Bagi Pekerja Rumah Tangga Melalui Kepastian Hukum' (2020) 17 Legislasi Indonesia.

Makmur SM and Mohammad IR, 'Tinjauan Hukum Perlindungan Tehadap Pekerja Rumah Tangga' (2020) 1 Jurnal At-Tanwir Law Review.

Maslihati Hidayati, 'Upaya Perlindungan Pekerja Rumah Tangga Sebagai Kelompok Masyarakat Yang Termarjinalkan Di Indonesia' [2011] Jurnal AlAzhar Indonesia.

Mulyanto KD, 'Urgensi Ratifikasi Konvensi Pekerjaan Yang Layak Bagi Pekerja Rumah Tangga Oleh Pemerintah Indonesia' (2018) 1 Undang: Jurnal Hukum.

Muwahid, 'Perlindungan Hukum Terhadap Buruh Wanita Sektor Pekerja Rumah Tangga (PRT) Di Kota Surabaya' (2017) 1 Mimbar Yustiti.

Nur Hidayati, 'Perlindungan Terhadap Pembantu Rumah Tangga (PRT) Menurut Permenaker No . 2 Tahun 2015’ (2014) 14 Ragam Jurnal Pengembangan Humaniora Jurnal Pengembangan Humaniora.

Pariutami A and Udiana IM, 'Perlindungan Hukum Terhadap Hak Pekerja Rumah Tangga Yang Tidak Sesuai Dengan Perjanjian Dibawah Tangan' (2020) 8 Kertha Semaya, Jurnal Ilmu Hukum.

Raflis RI, Rochaeti N and Wijaningsih D, 'Perlindungan Hukum Bagi Pekerja Rumah Tangga Perempuan Korban Tindak Kekerasan' (2016) 5 Diponegoro law.

Ranny Intan Raflis NR and DW, 'Perlindungan Hukum Bagi Pekerja Rumah Tangga Perempuan Korban Tindak Kekerasan’ (2016) 5 Diponegoro law Journal.

Sitti Magfirah Makmur dan Irwansyah Reza Mohammad, 'Tinjauan Hukum Perlindungan Tehadap Pekerja Rumah Tangga' (2020) 1 Jurnal At-Tanwir Law Review.

Sonhaji, 'Perlindungan Pekerja Rumah Tangga Dalam Sistem Hukum Nasional' (2020) 3 Administrative Law and Governance Journal.

Utama G and Melinda V, 'Pengaturan Dan Perlindungan Hukum Bagi Pekerja Rumah Tangga Di Indonesia' (2018) 11 Arena hukum. 


\section{Perundang-undangan}

Undang-Undang Republik Indonesia No. 13 Tahun 2003 tentang ketenagakerjaan (Lembaran Negara Republik Indonesia Tahun 2003 Nomor 39).

Peraturan Menteri Ketenagakerjaan No. 2 Tahun 2015 tentang Perlidungan Pekerja Rumah Tangga (Berita Negara Republik Indonesia Tahun 2015 Nomor 78).

How to cite: Muhammad Yafi Azhari dan Abdul Halim, 'Hak-Hak Pekerja Rumah Tangga dan Perlindungan Hukum di Indonesia' (2021) Vol. 4 No. 2 Media Iuris. 
--Halaman ini sengaja dibiarkan kosong-- 